

\title{
Ticks collected from birds in the northern provinces of South Africa, 2004-2006
}

\author{
G. HASLE ${ }^{1 *}$, I.G. HORAK², G. GRIEVE ${ }^{3}$, H.P. LEINAAS ${ }^{4}$ and F. CLARKE ${ }^{5}$
}

\begin{abstract}
HASLE, G., HORAK, I.G., GRIEVE, G., LEINAAS, H.P. \& CLARKE, F. 2009. Ticks collected from birds in the northern provinces of South Africa, 2004-2006. Onderstepoort Journal of Veterinary Research, 76:167-175

Approximately 3000 birds, mainly passerines, caught in mist nets in the northern provinces of South Africa, were examined for ticks. A total of 178 ticks, belonging to 14 species, were recovered from 83 birds of 43 different species. Hyalomma rufipes was the most numerous tick, with 26 larvae and 109 nymphs collected, followed by Amblyomma marmoreum, with 13 larvae and two nymphs. Despite the study being conducted within the distribution range of Amblyomma hebraeum, it was not seen on any passerines, whereas three larger species were infested. The potential for small birds to spread ticks with their associated tick-borne pathogens is discussed.
\end{abstract}

Keywords: Amblyomma marmoreum, birds, Hyalomma rufipes, migration, northern South Africa, passerines, ticks

\section{INTRODUCTION}

Ticks are important vectors of pathogens affecting humans and livestock, and may themselves cause anaemia, hide damage, and wounds resulting in secondary bacterial infections (Fletcher 2007). An understanding of their dispersal mechanisms is cru-

* Author to whom correspondence is to be directed. E-mail: hasle@reiseklinikken.no

1 Oslo Travel Clinic, St Olavs plass 3, NO-0165 Oslo, Norway

2 Department of Veterinary Tropical Diseases, Faculty of Veterinary Science, University of Pretoria, Private Bag X04, Onderstepoort, 0110 South Africa, and Department of Zoology and Entomology, University of the Free State, P.O. Box 339, Bloemfontein, 9300 South Africa

3 Birdlife Northern Gauteng Ringing Group, 344 Delphinus Street, Waterkloof Ridge, Pretoria, 0181 South Africa

4 Department of Biology, University of Oslo, P.O. Box 1066 Blindern, NO-0316 Oslo, Norway

5 Department of Biology, University of Limpopo (Medunsa Campus), P.O. Box 139, Medunsa, 0204 South Africa

Accepted for publication 22 August 2008-Editor cial towards their effective control. Ticks have very limited locomotor ability and rely on their hosts for dispersal. Migratory birds can serve as hosts for several tick species (Hoogstraal, Kaiser, Traylor, Gaber \& Guindy 1961; Hoogstraal, Kaiser, Traylor, Guindy \& Gaber 1963; Hoogstraal 1972; Mehl, Michaelsen \& Lid 1984; Olsén, Jaenson \& Bergström 1995), and may transport these with their associated tick-borne pathogens across geographical barriers such as deserts and oceans. In addition, larger, ground-living birds, such as Francolin, Spurfowl and Guineafowl, are important hosts for the immature stages of certain tick species, and are often heavily infested (Horak \& Williams 1986; Horak, Fourie, Novellie \& Williams 1991a; Horak, Spickett, Braack \& Williams 1991b; Horak \& Boomker 1998; Uys \& Horak 2005). Although passerines and other small birds usually harbour only small numbers of ticks, they often occur in flocks, and thus, because of their large numbers and extraordinary mobility, have the potential of significantly contributing to pathogen dispersal as well as tick gene flow within a region. It 
is especially birds that may introduce certain tick species with their associated tick-borne pathogens to new areas, once climate change or human impact has made these habitable for them. Birds readily cross fences between wildlife reserves and pastures used by domestic livestock, and may thus transfer both ticks and tick-borne pathogens from their potential wildlife reservoirs to domestic animals. Moreover acaricide resistance is a considerable problem in some regions of Africa (Fletcher 2007), and it is not entirely unlikely that birds play some role in the spread of acaricide-resistant strains of ticks.

Few data sets exist on the ticks that infest small birds in sub-Saharan Africa. However, Horak et al. (1991a) have recorded the immature stages of two tick species on four species of small birds in the Eastern Cape Province, South Africa and in a more recent study Van Niekerk, Fourie \& Horak (2006) recorded ticks on 39 species of birds in the Free State Province, South Africa. Amongst the latter there were 28 different passerine species. Our objective in the present study was to provide additional data on ticks and the species of birds that they might infest, as well as on the bird species that could be important in spreading ticks.

\section{MATERIALS AND METHODS}

The bird-ringing excursions of amateur ornithologists provide a valuable opportunity for the collection of ectoparasites from the birds they have captured. This study was carried out in collaboration with the members of the Pretoria Bird Ringing Club during their activities at various localities in the provinces of Gauteng, Limpopo, Mpumalanga and North
West, South Africa (Table 1). The birds were caught in mist nets and examined for ticks using headmounted magnifying glasses. The examination concentrated on the head of the birds, especially the eyelids, around the beak and in the ears, where the vast majority of ticks usually occur on passerines (Mehl et al. 1984; Smith 2001). The bare skin under the wings, the brood patch and the region around the cloaca were also frequently examined, but these sites yielded no ticks. The examination for ticks increased the handling time of the birds by about one minute. Ticks and other ectoparasites were collected by means of forceps and placed in separate vials containing $70 \%$ ethanol, together with a label recording date, ring number, locality and bird species. We have followed the nomenclature proposed by Hockey, Dean \& Ryan (2005) for the birds we examined, and their migration and feeding habits are summarized in Appendix 1. Approximately 3000 birds were examined, but unfortunately the documents recording the exact number were lost.

\section{RESULTS}

The method of trapping birds in mist nets is suitable only for small birds, and most of the birds caught were passerines. Out of a total of approximately 3000 birds examined, belonging to 43 species, we recovered 178 ticks from 83 of them. The ticks comprised 48 larvae, 124 nymphs and six adults belonging to 14 species (Table 2). Among these were one Argas, one Hyalomma and an Ixodes species that we could not identify. The birds that harboured most ticks were Olive Thrush and Cape Robin-Chat. The most numerous tick collected was Hyalomma rufipes, comprising 26 larvae and 109 nymphs. The second most common species was Amblyomma

TABLE 1 Localities at which ticks were collected from birds in the northern provinces of South Africa

\begin{tabular}{|c|l|l|l|}
\hline No. & Locality & \multicolumn{2}{l|}{ Coordinates } \\
\hline 1 & Buffelsdrift, Pretoria & $25^{\circ} 35^{\prime} \mathrm{S}$ & $28^{\circ} 20^{\prime} \mathrm{E}$ \\
2 & Colbyn, Pretoria & $25^{\circ} 44^{\prime} \mathrm{S}$ & $28^{\circ} 15^{\prime} \mathrm{E}$ \\
3 & Groenkloof, Pretoria & $25^{\circ} 47^{\prime} \mathrm{S}$ & $28^{\circ} 12^{\prime} \mathrm{E}$ \\
4 & Jaleoda & $25^{\circ} 57^{\prime} \mathrm{S}$ & $28^{\circ} 35^{\prime} \mathrm{E}$ \\
5 & Ntsinini, Sagewood cottage & $25^{\circ} 36^{\prime} \mathrm{S}$ & $30^{\circ} 23^{\prime} \mathrm{E}$ \\
6 & Nylsvley & $24^{\circ} 39^{\prime} \mathrm{S}$ & $28^{\circ} 42^{\prime} \mathrm{E}$ \\
7 & Olifantskop & $23^{\circ} 58^{\prime} \mathrm{S}$ & $27^{\circ} 28^{\prime} \mathrm{E}$ \\
8 & Rietvlei & $25^{\circ} 55^{\prime} \mathrm{S}$ & $28^{\circ} 18^{\prime} \mathrm{E}$ \\
9 & Samrand, Midrand & $25^{\circ} 55^{\prime} \mathrm{S}$ & $28^{\circ} 08^{\prime} \mathrm{E}$ \\
10 & Suikerbosrand NR, Kareekloof gate & $26^{\circ} 31^{\prime} \mathrm{S}$ & $28^{\circ} 10^{\prime} \mathrm{E}$ \\
11 & Sunbird Hill, Kameelfontein & $25^{\circ} 38^{\prime} \mathrm{S}$ & $28^{\circ} 24^{\prime} \mathrm{E}$ \\
12 & Wakkerstroom & $27^{\circ} 21^{\prime} \mathrm{S}$ & $30^{\circ} 06^{\prime} \mathrm{E}$ \\
13 & Retirement forest, Wakkerstroom & $27^{\circ} 18^{\prime} \mathrm{S}$ & $30^{\circ} 19^{\prime} \mathrm{E}$ \\
\hline
\end{tabular}


TABLE 2 Ticks collected from 83 infested birds in the northern provinces of South Africa (immature stages when not otherwise indicated)

\begin{tabular}{|c|c|c|c|c|}
\hline \multirow{2}{*}{ Tick and bird species } & \multirow{2}{*}{ Bird species names } & \multicolumn{2}{|l|}{ No. } & \multirow{2}{*}{ Localities* } \\
\hline & & Birds & Ticks & \\
\hline \multicolumn{5}{|l|}{ Argas species } \\
\hline Cardinal Woodpecker & Dendropicos fuscescens & 1 & 1 & 7 \\
\hline \multicolumn{5}{|l|}{ Amblyomma hebraeum } \\
\hline $\begin{array}{l}\text { Swainson's Spurfowl } \\
\text { Southern Yellow-billed Hornbill } \\
\text { Double-banded Sandgrouse }\end{array}$ & $\begin{array}{l}\text { Pternistis swainsonii } \\
\text { Tockus leucomelas } \\
\text { Pterocles bicinctus }\end{array}$ & $\begin{array}{l}1 \\
2 \\
1\end{array}$ & $\begin{array}{l}1 \\
2 \\
1\end{array}$ & $\begin{array}{l}1 \\
7 \\
7\end{array}$ \\
\hline \multicolumn{5}{|l|}{ Amblyomma marmoreum } \\
\hline $\begin{array}{l}\text { Double-banded Sandgrouse } \\
\text { Cattle Egret } \\
\text { Brown-crowned Tchagra } \\
\text { Red-headed Weaver } \\
\text { Red-billed Quelea } \\
\text { Cinnamon-breasted Bunting }\end{array}$ & $\begin{array}{l}\text { Pterocles bicinctus } \\
\text { Bubulcus ibis } \\
\text { Tchagra australis } \\
\text { Anaplectes melanotis } \\
\text { Quelea quelea } \\
\text { Emberiza tahapisi }\end{array}$ & $\begin{array}{l}1 \\
1 \\
2 \\
1 \\
1 \\
6\end{array}$ & $\begin{array}{l}2 \\
2 \\
2 \\
1 \\
1 \\
7\end{array}$ & $\begin{array}{l}7 \\
1 \\
7, \cup \\
7 \\
7 \\
7\end{array}$ \\
\hline \multicolumn{5}{|l|}{ Haemaphysalis elliptica } \\
\hline $\begin{array}{l}\text { Rattling Cisticola } \\
\text { Levailant's Cisticola } \\
\text { Long-tailed Widowbird }\end{array}$ & $\begin{array}{l}\text { Cisticola chiniana } \\
\text { Cisticola tinniens } \\
\text { Euplectes progne }\end{array}$ & $\begin{array}{l}1 \\
2 \\
1\end{array}$ & $\begin{array}{l}1 \\
3 \\
1\end{array}$ & $\begin{array}{l}1 \\
3,12 \\
8\end{array}$ \\
\hline \multicolumn{5}{|l|}{ Haemaphysalis hoodi } \\
\hline Striped Pipit ${ }^{1}$ & Anthus lineiventris & 1 & 1 & 5 \\
\hline \multicolumn{5}{|l|}{ Hyalomma glabrum } \\
\hline $\begin{array}{l}\text { Red-billed Quelea } \\
\text { Cinnamon-breasted Bunting }\end{array}$ & $\begin{array}{l}\text { Quelea quelea } \\
\text { Emberiza tahapisi }\end{array}$ & $\begin{array}{l}1 \\
1\end{array}$ & $\begin{array}{l}1 \\
1\end{array}$ & $\begin{array}{l}7 \\
7\end{array}$ \\
\hline \multicolumn{5}{|l|}{ Hyalomma rufipes } \\
\hline $\begin{array}{l}\text { Striped Kingfisher } \\
\text { Red-faced Mousebird } \\
\text { Laughing Dove } \\
\text { Brown-crowned Tchagra } \\
\text { Southern Boubou } \\
\text { Crimson-breasted Shrike } \\
\text { Common Fiscal } \\
\text { Magpie Shrike } \\
\text { Southern Black Tit } \\
\text { Ashy Tit } \\
\text { Dark-capped Bulbul } \\
\text { Black-chested Prinia } \\
\text { Sabota Lark } \\
\text { Kurrichane Thrush } \\
\text { Olive Thrush } \\
\text { Marico Flycatcher } \\
\text { Southern Black Flycatcher } \\
\text { Cape Robin-chat } \\
\text { Wattled Starling }\end{array}$ & $\begin{array}{l}\text { Halcyon chelicuti } \\
\text { Urocolius indicus } \\
\text { Streptopelia senegalensis } \\
\text { Tchagra australis } \\
\text { Laniarius ferrugineus } \\
\text { Laniarius atrococcineus } \\
\text { Lanius collaris } \\
\text { Corvinella melanoleuca } \\
\text { Parus niger } \\
\text { Parus cinerascens } \\
\text { Pycnonotus tricolor } \\
\text { Prinia flavicans } \\
\text { Calendulauda sabota } \\
\text { Turdus libonyanus } \\
\text { Turdus olivaceus } \\
\text { Bradornis mariquensis } \\
\text { Melaenornis pammelaina } \\
\text { Cossypha caffra } \\
\text { Creatophora cinerea }\end{array}$ & $\begin{array}{l}1 \\
1 \\
1 \\
3 \\
2 \\
1 \\
1 \\
1 \\
2 \\
3 \\
2 \\
1 \\
1 \\
2 \\
2 \\
2 \\
2 \\
7 \\
1\end{array}$ & $\begin{array}{l}3 \\
1 \\
1 \\
13 \\
2 \\
1 \\
1 \\
1 \\
4 \\
7 \\
2 \\
1 \\
2 \\
2 \\
26 \\
5 \\
3 \\
25 \\
1\end{array}$ & $\begin{array}{l}11 \\
7 \\
7 \\
1,7,10 \\
1,5 \\
7 \\
1 \\
1 \\
7 \\
7 \\
3 \\
10 \\
7 \\
3,5 \\
10 \\
7 \\
6, U \\
1,10, \mathrm{U} \\
10\end{array}$ \\
\hline
\end{tabular}




\begin{tabular}{|c|c|c|c|c|}
\hline \multirow{2}{*}{ Tick and bird species } & \multirow{2}{*}{ Bird species names } & \multicolumn{2}{|l|}{ No. } & \multirow{2}{*}{ Localities* } \\
\hline & & Birds & Ticks & \\
\hline $\begin{array}{l}\text { Lesser Masked-weaver } \\
\text { Southern Masked-weaver } \\
\text { Red-billed Quelea } \\
\text { Blue Waxbill } \\
\text { Pin-tailed Whydah } \\
\text { Cape Longclaw }\end{array}$ & $\begin{array}{l}\text { Ploceus intermedius } \\
\text { Ploceus velatus } \\
\text { Quelea quelea } \\
\text { Uraeginthus angolensis } \\
\text { Vidua macroura } \\
\text { Macronyx capensis }\end{array}$ & $\begin{array}{l}1 \\
4 \\
3 \\
1 \\
1 \\
1\end{array}$ & $\begin{array}{l}1 \\
19 \\
3 \\
1 \\
1 \\
9\end{array}$ & $\begin{array}{l}7 \\
7,11 \\
4,7 \\
1 \\
7 \\
10\end{array}$ \\
\hline \multicolumn{5}{|l|}{ Hyalomma species } \\
\hline Cinnamon-breasted Bunting & Emberiza tahapisi & 1 & 1 & 7 \\
\hline \multicolumn{5}{|l|}{ Ixodes pilosus group } \\
\hline $\begin{array}{l}\text { Levaillant's Cisticola } \\
\text { Yellow-crowned Bishop }\end{array}$ & $\begin{array}{l}\text { Cisticola tinniens } \\
\text { Euplectes afer }\end{array}$ & $\begin{array}{l}1 \\
1\end{array}$ & $\begin{array}{l}1 \\
1\end{array}$ & $\begin{array}{l}2 \\
4\end{array}$ \\
\hline \multicolumn{5}{|l|}{ Ixodes species } \\
\hline $\begin{array}{l}\text { Bar-throated Apalis } \\
\text { Cape Robin-chat } \\
\text { Blue Waxbill }\end{array}$ & $\begin{array}{l}\text { Apalis thoracica } \\
\text { Cossypha caffra } \\
\text { Uraeginthus angolensis }\end{array}$ & $\begin{array}{l}2 \\
1 \\
1\end{array}$ & $\begin{array}{l}2 \\
1 \\
1\end{array}$ & $\begin{array}{l}5 \\
5 \\
11\end{array}$ \\
\hline \multicolumn{5}{|l|}{ Ixodes spinae } \\
\hline Southern Red Bishop 1,2 & Euplectes orix & 1 & 1 & 9 \\
\hline \multicolumn{5}{|l|}{ Ixodes theilerae } \\
\hline $\begin{array}{l}\text { Cape Batis }{ }^{2} \\
\text { Olive Thrush }{ }^{3} \\
\text { Cape Weaver }{ }^{1,2}\end{array}$ & $\begin{array}{l}\text { Batis capensis } \\
\text { Turdus olivaceus } \\
\text { Ploceus capensis }\end{array}$ & $\begin{array}{l}1 \\
1 \\
1\end{array}$ & $\begin{array}{l}1 \\
1 \\
1\end{array}$ & $\begin{array}{l}13 \\
10 \\
10\end{array}$ \\
\hline \multicolumn{5}{|c|}{ Rhipicephalus (Boophilus) decoloratus } \\
\hline Three-banded Plover & Charadrius tricollaris & 1 & 1 & 1 \\
\hline \multicolumn{5}{|l|}{ Rhipicephalus turanicus } \\
\hline Marsh Owl ${ }^{4}$ & Asio capensis & 1 & 3 & 6 \\
\hline
\end{tabular}

\footnotetext{
* Numbers in this column refer to localities in Table 1

Tick species identity uncertain

2 Adult tick: female

3 The same bird also carried two nymphs of $H$. rufipes

4 Adult ticks: one female, two males

$\mathrm{U}=$ unknown
}

marmoreum, with 13 larvae and two nymphs. Five specimens of Haemaphysalis elliptica were also recovered, one of these from a Rattling Cisticola and three from Levailant's Cisticola. No other ticks were found on Cisticola. Between one and four specimens of the remaining tick species were collected. Amblyomma hebraeum was not found on any of the smaller birds, but was present on Swainson's Spur- fowl, Southern Yellow-billed Hornbill and Doublebanded Sandgrouse. A single Rhipicephalus (Boophilus) decoloratus larva was collected from a Three-banded Plover.

The only adult ticks recovered were Ixodes spinae, Ixodes theilerae and Rhipicephalus turanicus. The sole Argas specimen was a larva collected from a Cardinal Woodpecker. 


\section{DISCUSSION}

Most ticks were recovered from birds that feed mainly on the ground, in particular members of the family Turdidae. This agrees with the results of an earlier study conducted elsewhere (Olsén et al. 1995). Only a few of the mainly arboreal bird species that we examined harboured ticks, e.g. the Dark-capped Bulbul and the Lesser Masked-
Weaver (see Appendix 1). Because these species are often caught in nets, it is sometimes possible to detect even a low rate of tick infestation on them.

After an exhaustive study of numerous specimens of all stages of development of the subspecies of the Hyalomma marginatum group, Apanaskevich \& Horak (2008) concluded that these ticks should be treated as independent species, namely $H$. margi-

APPENDIX 1 Species characteristics of the tick-infested birds in the study (Hockey et al. 2005)

\begin{tabular}{|c|c|c|}
\hline Bird species & Migration habits & Feeding habitats \\
\hline Swainson's Spurfowl* & Resident and sedentary & On ground \\
\hline Cardinal Woodpecker* & Resident and sedentary & In trees \\
\hline Southern Yellow-billed Hornbill* & $\begin{array}{l}\text { Resident and sedentary. Rarely forms small flocks } \\
\text { during dry season and drought }\end{array}$ & Mainly on the ground \\
\hline Striped Kingfisher* & Resident, with some local movement & $\begin{array}{l}\text { Mainly on ground in arid } \\
\text { areas }\end{array}$ \\
\hline Red-faced Mousebird* & $\begin{array}{l}\text { Generally resident, locally nomadic in response to } \\
\text { phenology of fruiting trees. Altitudinal migrant }\end{array}$ & Flowers and fruits \\
\hline Marsh Owl $\left.\right|^{*}$ & Resident where habitat is stable, otherwise nomadic & $\begin{array}{l}\text { Lives on ground, eats } \\
\text { rodents }\end{array}$ \\
\hline Laughing Dove* & $\begin{array}{l}\text { Largely sedentary with some local nomadic } \\
\text { movements }\end{array}$ & Open ground \\
\hline Double-banded Sandgrouse* & Sedentary. May move in search of water & On ground \\
\hline Three-banded Plover* & $\begin{array}{l}\text { Sedentary. Partial intra-African migrant in response to } \\
\text { seasonal rainfall }\end{array}$ & On open shores \\
\hline Cattle Egret ${ }^{*}$ & Moves over large distances & On ground \\
\hline Brown-crowned Tchagra & Resident and sedentary & On ground \\
\hline Southern Boubou & Resident and sedentary & On ground \\
\hline Crimson-breasted Shrike & $\begin{array}{l}\text { Resident and sedentary, but may move locally to } \\
\text { riverine woodland during non-breeding season }\end{array}$ & On ground and in trees \\
\hline Cape Batis & Resident. Altitudinal migration & In trees \\
\hline Common Fiscal & Mostly resident and sedentary, possibly nomadic & $\begin{array}{l}\text { Small prey usually eaten on } \\
\text { ground }\end{array}$ \\
\hline Magpie Shrike & $\begin{array}{l}\text { Resident and generally sedentary, but may move } \\
\text { locally in response to drought and fires }\end{array}$ & Mostly on ground \\
\hline Southern Black Tit & Resident & $\begin{array}{l}\text { Mainly in trees, eats } \\
\text { earthworms after rain }\end{array}$ \\
\hline Ashy Tit & Resident and locally nomadic & $\begin{array}{l}\text { In bushes, less frequently on } \\
\text { ground }\end{array}$ \\
\hline Dark-capped Bulbul & $\begin{array}{l}\text { Sedentary. Some local dispersal linked to food } \\
\text { availability }\end{array}$ & $\begin{array}{l}\text { In trees, occasionally on } \\
\text { ground }\end{array}$ \\
\hline Rattling Cisticola & Resident & $\begin{array}{l}\text { Low in grass or bushes, or } \\
\text { on ground }\end{array}$ \\
\hline Levailant's Cisticola & Mostly resident, may undertake local movements & Low down in vegetation \\
\hline
\end{tabular}




\begin{tabular}{|c|c|c|}
\hline Bird species & Migration habits & Feeding habitats \\
\hline Black-chested Prinia & Resident. Probably locally nomadic & $\begin{array}{l}\text { In bushes, less frequently on } \\
\text { ground }\end{array}$ \\
\hline Bar-throated Apalis & $\begin{array}{l}\text { Resident and sedentary. Some winter movements to } \\
\text { lower altitudes }\end{array}$ & Partly on ground \\
\hline Sabota Lark & $\begin{array}{l}\text { Resident and sedentary, locally nomadic in drier part } \\
\text { of range }\end{array}$ & On ground \\
\hline Kurrichane Thrush & Mainly resident. Some altitudinal migration & On ground \\
\hline Olive Thrush & $\begin{array}{l}\text { Mostly resident, altitudinal migrant, and in response } \\
\text { to drought }\end{array}$ & Mostly on ground \\
\hline Marico Flycatcher & Resident & Mostly on ground \\
\hline Southern Black Flycatcher & Resident & Partly on ground \\
\hline Cape Robin-Chat & Altitudinal migrant & $\begin{array}{l}\text { Spends much time on } \\
\text { ground }\end{array}$ \\
\hline Wattled Starling & Nomadic & Mostly on ground \\
\hline Lesser Masked-Weaver & Resident, sedentary and local nomad & In tree canopies \\
\hline Cape Weaver & $\begin{array}{l}\text { Mostly resident and sedentary, with some local } \\
\text { movements. } 5 \% \text { move }>100 \mathrm{~km}\end{array}$ & On ground \\
\hline Southern Masked-Weaver & Resident, sedentary and partial migrant & $\begin{array}{l}\text { On ground, grass stems and } \\
\text { trees }\end{array}$ \\
\hline Red-headed Weaver & $\begin{array}{l}\text { In Botswana, moves out of deciduous woodland in dry } \\
\text { season; in Zimbabwe, range contracts in non-breed- } \\
\text { ing season }\end{array}$ & $\begin{array}{l}\text { Mainly in trees, bushes and } \\
\text { creepers }\end{array}$ \\
\hline Red-billed Quelea & Large scale movements throughout range & On ground \\
\hline Yellow-crowned Bishop & $\begin{array}{l}\text { Resident and locally nomadic. Migratory in West } \\
\text { Africa }\end{array}$ & $\begin{array}{l}\text { On ground or directly from } \\
\text { plants }\end{array}$ \\
\hline Southern Red Bishop & $\begin{array}{l}\text { Resident and sedentary, some local movement in } \\
\text { non-breeding season }\end{array}$ & $\begin{array}{l}\text { Both on ground and perched } \\
\text { in vegetation }\end{array}$ \\
\hline Long-tailed Widowbird & $\begin{array}{l}\text { Resident and sedentary, local movement in non- } \\
\text { breeding season. }\end{array}$ & Largely on ground \\
\hline Blue Waxbill & Mostly resident. May move nomadically in winter & On ground and in vegetation \\
\hline Pin-tailed Whydah & $\begin{array}{l}\text { Resident and sedentary. Nomadic in non-breeding } \\
\text { season }\end{array}$ & Eat seeds on ground \\
\hline Cape Longclaw & Resident. Form groups on burnt ground in winter & On ground \\
\hline Striped Pipit & $\begin{array}{l}\text { Resident and sedentary, possibly with some local } \\
\text { movement }\end{array}$ & On ground \\
\hline Cinnamon-breasted Bunting & Resident, but migrant from Nov-Dec to April-May & On ground \\
\hline
\end{tabular}

${ }^{*}$ = non-passerine species

natum, $H$. rufipes, $H$. isaaci and $H$. turanicum, and we have followed their recommendation. Hyalomma rufipes was the most prevalent tick species on small birds in our survey as well as in other studies (Hoogstraal et al. 1961; Van Niekerk et al. 2006). Adult $H$. rufipes feed on large ungulates (Norval 1982), and the immature stages feed on birds (Horak et al. 1991b; Uys \& Horak 2005; Van Niekerk et al. 2006), and hares (Horak \& Fourie 1991). It is patchily distributed in Africa, Europe and Western and Central Asia (Walker, Bouattour, Camicas, Estrada-Peña, Horak, Latif, Pegram \& Preston 2003), and is the most important vector of Crimean-Congo haemorrhagic fever (CCHF) virus to humans in South Africa 
(Horak, Swanepoel \& Gummow 2002). In Africa it may also transmit Anaplasma marginale, Rickettsia conorii and Babesia occultans (Walker et al. 2003). Unlike other tick species, of which the immature stages tend to infest mainly larger birds, $H$. rufipes is found on passerines (Cumming 1998) as well as on larger species such as Crested Francolin and Helmeted Guineafowl (Horak et al. 1991b; Uys and Horak 2005). It is a two-host tick, which, like its close relative $H$. marginatum, probably remains attached to the host for 12 to 26 days from the start of feeding of the larva to detachment of the engorged nymph (Hueli 1979). This prolonged period of attachment plays an important role in the long-distance transportation of ticks with their associated tick-borne pathogens.

The immature stages of Hyalomma glabrum, which we collected from two birds, infest hares and birds (Apanaskevich \& Horak 2006). This tick, which was previously thought to be Hyalomma turanicum, a known vector of CCHF, has recently been re-established as a valid species (Apanaskevich \& Horak 2006).

Adult $A$. marmoreum, the second most common species recovered in this study, feed nearly exclusively on tortoises (Horak, McKay, Heyne \& Spickett 2006). Its immature stages feed on a wide range of hosts, including tortoises and birds (Horak et al. 2006; Van Niekerk et al. 2006). This tick may play a role in the transmission of Ehrlichia ruminantium to domestic ruminants (Norval \& Horak 2004). Amblyomma hebraeum, which in the present study was collected from three of the larger bird species, is the major vector of $E$. ruminatium in South Africa (Norval \& Horak 2004). It also transmits Theileria mutans to cattle, and Rickettsia africae to humans. Its distribution is confined to south-eastern Africa (Walker et al. 2003), and it is the tick species of which the immature stages have most often been recorded biting humans in South Africa (Horak, Fourie, Heyne, Walker \& Needham 2002). The adults prefer large ungulates, while the immature stages parasitize large and small ungulates as well as large ground living birds (Walker et al. 2003). Within its distribution range the immature stages of $A$. hebraeum are the most common ticks found on Helmeted Guineafowl (Horak \& Williams 1986; Horak et al. 1991b), and they are also common on Crested Francolin (Uys \& Horak 2005). Despite large numbers of birds being examined in earlier studies, adult ticks were not encountered on them (Horak \& Williams 1986; Horak et al. 1991b; Uys \& Horak 2005). Amblyomma hebraeum is apparently not spread by small birds, as no ticks of this species were collected from passerines and other small birds in our study, even though it was conducted within the distribution range of the tick.

Haemaphysalis elliptica (formerly H. leachi) (Apanaskevich, Horak \& Camicas 2007), the third most common tick collected (Table 2), is a major vector of Babesia canis to dogs, and can transmit $R$. conorii to humans. It is a parasite of large domestic and wild carnivores, and is widespread in southern Africa (Apanaskevich et al. 2007). True H. leachi is found in the Nile delta and north-east Africa (Walker et al. 2003). The immature stages of $H$. elliptica are not common parasites of birds. Van Niekerk et al. (2006) recovered a single nymph from birds in Free State Province, while Horak et al. (1991b) collected only three larvae and two nymphs from 118 Helmeted Guineafowl, as opposed to 23778 A. hebraeum and 2387 A. marmoreum larvae and nymphs from the same birds in a habitat in which all three tick species were abundant.

It is not known whether Haemaphysalis hoodi and $I$. theilerae, which parasitize birds, and I. spinae which infests birds, hyraxes and rodents (Cumming 1998), or Ixodes pilosus, which parasitizes wild and domestic ungulates and dogs, transmit any pathogens (Walker et al. 2003).

Rhipicephalus (Boophilus) decoloratus transmits Babesia bigemina, A. marginale and Borrelia theileri, the first two of which are causes of cattle diseases of immense veterinary importance in South Africa. This is a one-host tick (Walker et al. 2003), and should be considered an accidental parasite of birds, on which it is unlikely to complete its life cycle. Rhipicephalus turanicus belongs to the Rhipicephalus sanguineus complex, and could be a vector of Rickettsiae of the Spotted fever group (Matsumoto, Ogawa, Brouqui, Raoult \& Parola 2005). Large carnivores and large ground-living birds are hosts of the adults of this species (Walker, Keirans \& Horak 2000), which we collected from a Marsh Owl.

Argasids are typically endophilic (burrow or nestdwelling) (Hillyard 1996), and this may explain why an Argas species was found on a woodpecker.

We found no tick species in this study that had not previously been recorded in the same stage of development on birds (Cumming 1998; Walker et al. 2003). Our results agree with those of previous surveys in that the immature stages of $H$. rufipes are the most common tick species found on passerines and other small land birds, followed by $A$. mar- 
moreum, while other ticks seem to be rare or occasional parasites (Horak et al. 1991a; Van Niekerk et al. 2006).

Strangely, none of the ticks recovered in this study were from migratory birds that breed in temperate regions, and which travel large distances every day during the migration seasons. Few South African birds migrate regularly. Red-billed Quelea and Cinnamon-breasted Bunting are nomadic when not breeding (Sinclair, Hockey \& Tarboton 2002), and may therefore be important in long distance dispersal of ticks. Sedentary birds like Cape Robin-Chat may move within their distributional range during winter, or to KwaZulu Natal, where they are seen as winter visitors (Sinclair et al. 2002). Some species are altitudinal migrants, e.g. Bar-Throated Apalis and Cape Robin-Chat (Hockey et al. 2005). Almost all bird species move about in search of food and water, particularly during harsh environmental conditions, and may thereby also transport ticks.

\section{CONCLUSION}

Birds that feed on the ground are predisposed to tick infestation, but there are also considerable differences among tick species in their predisposition and ability to infest birds. The immature stages of $H$. rufipes and $A$. marmoreum infest small birds, like passerines, but they may also infest larger birds. Conversely the immature instars of $A$. hebraeum infest larger birds, but apparently not passerines. The overall widespread distribution of $H$. rufipes may in part be ascribed to its tendency to infest passerines. Ticks (including acaricide-resistant ticks) with their associated tick-borne pathogens may be dispersed over large distances via bird migration. Smaller birds, through their huge numbers, may play a role as hosts for ticks, but no ticks of medical or veterinary importance seem to use small birds as maintenance hosts.

\section{ACKNOWLEDGEMENTS}

This survey is a part of an ectoparasite study approved by the ethical and scientific review committee of the University of Limpopo (Medunsa Campus). G. Hasle's participation in the study was supported by a travel grant from Abbott, Norway.

\section{REFERENCES}

APANASKEVICH, D.A., \& HORAK, I.G. 2006. The genus Hyalomma Koch, 1844. I. Reinstatement of Hyalomma (euhya- lomma) glabrum Delpy, 1949 (Acari, Ixodidae) as a valid species with a redescription of the adults, the first description of its immature stages and notes on its biology. Onderstepoort Journal of Veterinary Research, 73:1-12.

APANASKEVICH, D.A., HORAK, I.G. \& CAMICAS, J-L. 2007. Redescription of Haemaphysalis (Rhipistoma) elliptica (Koch, 1844), an old taxon of the Haemaphysalis (Rhipistoma) leachi group from East and southern Africa, and of Haemaphysalis (Rhipistoma) leachi (Audouin, 1826) (Ixodida, Ixodidae). Onderstepoort Journal of Veterinary Research, 74: 181-207.

APANASKEVICH, D.A. \& HORAK, I.G. 2008. The genus Hyalomma Koch, 1844. V. Re-evaluation of the taxonomic rank of taxa comprising the $H$. (Euhyalomma) marginatum group of species (Acari: Ixodidae) with redescription of all parasitic stages and notes on biology. International Journal of Acarology, 34:13-42.

CUMMING, G.S. 1998. Host preference in African ticks (Acari: Ixodida): a quantitative data set. Bulletin of Entomological Research, 88:379-406.

FLETCHER, W.A. 2007. A guide to practical tick control in Southern Africa. Intervet (Pty) Ltd: Malelane Research Unit, Malelane.

HILLYARD, P.D. 1996. Ticks of North-West Europe, in Synopses of the British Fauna (new series), edited by R.S.K. Barnes \& J.H. Crothers. Shrewsbury: Field Studies Council, No. 52:12.

HOCKEY, P.A.R., DEAN, W.R.J. \& RYAN, P.G. 2005. Roberts birds of Southern Africa, VII ${ }^{\text {th }}$ ed. Cape Town: Trustees of the John Voelcker bird book fund. (Appendix 1).

HOOGSTRAAL, H., KAISER, M.N., TRAYLOR, M.A., GABER, S. \& GUINDY, E. 1961. Ticks (Ixodidea) on birds migrating from Africa to Europe and Asia. Bulletin of the World Health Organization, 24:197-212.

HOOGSTRAAL, H., KAISER, M.N., TAYLOR, M.A., GUINDY, E. \& GABER, S. 1963. Ticks (Ixodidea) on birds migrating from Europe and Asia to Africa. Bulletin of the World Health Organization, 28:235-262.

HOOGSTRAAL, H. 1972. Birds as tick hosts and reservoirs and disseminators of tickborne infectious agents. Wiadomosci Parasytologiczne T. XVIII, NR 4-5-6:703-706.

HORAK, I.G. \& WILLIAMS, E.J. 1986. Parasites of domestic and wild animals in South Africa. XVIII. The crowned guinea fowl (Numida meleagris), an important host of immature ixodid ticks. Onderstepoort Journal of Veterinary Research, 53: 119-122.

HORAK, I.G., FOURIE, L.J., NOVELLIE, P.A. \& WILLIAMS, E.J. 1991a. Parasites of domestic and wild animals in South Africa. XXVI. The mosaic of Ixodid tick infestation on birds and mammals in the Mountain Zebra National Park. Onderstepoort Journal of Veterinary Research, 58:125-136.

HORAK, I.G., SPICKETT, A.M., BRAACK, L.E.O. \& WILLIAMS, E.J. 1991b. Parasites of domestic and wild animals in South Africa. XXVII. Ticks on helmeted guineafowls in the eastern Cape Province and eastern Transvaal Lowveld. Onderstepoort Journal of Veterinary Research, 58:137-143.

HORAK, I.G. \& FOURIE, L.J. 1991. Parasites of domestic and wild animals in South Africa. XXIX. Ixodid ticks on hares in the Cape Province and on hares and red rock rabbits in the Orange Free State. Onderstepoort Journal of Veterinary Research, 58:261-270.

HORAK, I.G. \& BOOMKER, J. 1998. Parasites of domestic and wild animals in South Africa. XXXV. Ixodid ticks and bot fly larvae in the Bontebok National Park. Onderstepoort Journal of Veterinary Research, 65:205-211. 
HORAK I.G., SWANEPOEL, R. \& GUMMOW, B. 2002. The distribution of Hyalomma spp. and human cases of CrimeanCongo haemorrhagic fever in South Africa. Proceedings of the $10^{\text {th }}$ Conference of the Association of Institutions for Tropical Veterinary Medicine, Copenhagen, Denmark, 2023 August 2001:501-509.

HORAK, I.G., FOURIE, L.J., HEYNE, H., WALKER, J.B. \& NEEDHAM, G.R. 2002. Ixodid ticks feeding on humans in South Africa: with notes on preferred hosts, geographic distribution, seasonal occurrence and transmission of pathogens. Experimental and Applied Acarology, 27:113-136.

HORAK, I.G., MCKAY, I.J., HEYNE, HELOISE \& SPICKETT, A.M. 2006. Hosts, seasonality and geographic distribution of the South African tortoise tick, Amblyomma marmoreum. Onderstepoort Journal of Veterinary Research, 73:13-25.

HUELI, L.E. 1979. Estudio del ciclo biologico de Hyalomma marginatum marginatum Koch, 1844 (Acarinae: Ixodidae) bajo conditiones estandar de laboratorio. Revista Iberica Parasitologia, 39:143-152.

MATSUMOTO, K., OGAWA, M., BROUQUI, P., RAOULT, D. \& PAROLA, P. 2005. Transmission of Rickettsia massiliae in the tick, Rhipicephalus turanicus. Medical and Veterinary Entomology, 19:263-270.

MEHL, R., MICHAELSEN, J. \& LID, G. 1984. Ticks (Acari, Ixodides) on migratory birds in Norway. Fauna Norvay, Series B, 31:46-58.

NORVAL, R.A.I. 1982. The ticks of Zimbabwe. IV. The genus Hyalomma. Zimbabwe Veterinary Journal, 13:2-10.
NORVAL, R.A.I. \& HORAK, I.G. 2004. Vectors: ticks, in Infectious diseases of livestock, edited by J.A.W. Coetzer \& R.C. Tustin. Cape Town: Oxford University Press.

OLSÉN, B., JAENSON, T.G.T. \& BERGSTRÖM, S. 1995. Prevalence of Borrelia burgdorferi sensu lato-infected ticks on migrating birds. Applied and Environmental Microbiology, August: 3082-3087.

SINCLAIR, I., HOCKEY, P. \& TARBOTON, W. 2002. Sasol birds of southern Africa, $3^{\text {rd }}$ ed. Cape Town: Struik Publishers.

SMITH, V.S. 2001. Avian louse phylogeny (Phthiraptera: Ischnocera): a cladistic study based on morphology. Zoological Journal of the Linnean Society, 132:81-144.

UYS, A.C. \& HORAK, I.G. 2005. Ticks on crested francolins, Francolinus sephaena, and on the vegetation on a farm in Limpopo Province, South Africa. Onderstepoort Journal of Veterinary Research, 72:339-343.

VAN NIEKERK, D.J., FOURIE, L.J. \& HORAK, I.G. 2006. Birds as hosts of immature ticks in Free State Province, South Africa. Onderstepoort Journal of Veterinary Research, 73: 123-130.

WALKER, JANE B., KEIRANS, J.E. \& HORAK, I.G. 2000. The genus Rhipicephalus (Acari, Ixodidae): a guide to the brown ticks of the world. Cambridge: Cambridge Academic Press.

WALKER, A.R., BOUATTOUR, A., CAMICAS, J-L., ESTRADAPEÑA, A., HORAK, I.G., LATIF, A.A., PEGRAM, R.G. \& PRESTON, P.M. 2003. Ticks of domestic animals in Africa: a guide to identification of species. Edinburgh, Scotland: Bioscience Reports. 